\title{
Exploring Socio-economic Factors Contributing to the Emergence of large Age-gap Romantic Relationships Involving Older Women and Younger men in Chipata, Zambia
}

\author{
Jordan Tembo ${ }^{1}$, Patricia Mambwe ${ }^{2}$ \\ ${ }^{1}$ Kalindawalo General Hospital, P.O.Box 560008, Petauke, Zambia \\ ${ }^{2}$ Department of Nursing, School of Health Sciences, Rusangu University, Monze, Zambia \\ DOI: https://dx.doi.org/10.47772/IJRISS.2021.5325
}

\begin{abstract}
Older man-younger woman romantic relationship is a cultural normative relationship in all societies. A reversal characterized by an older woman-younger man intimancy is regarded as an offensive counterfeit of the genuine former. A woman found in this kind of a relationship, sleepy society wakes up, picks up verbal stones and breathes denunciations against the older woman and labels her a moral rebel for changing social norm-goal posts. The objective of this study was to investigate existence of large age-gap romantic relationships and to explore under what socio-economic climate did they emerge and thrive. The study was conducted between October to December, 2020. It was conducted in Chipata- Zambia. The study used a crosssectional design with a qualitative approach. A total of 30 participants were individually interviewed through the singleper-interview method. The study found that large age-gap older woman relationships were common, rampant and universal in both rural and urban areas with the latter scoring first. The study found that society defined large age-gap intimate heterosexual relationship involving an older woman as one where the woman was older than her male partner by 5 or more years. The study also found that some older women especially in villages engaged in romantic relationships with younger males because traditionally it was believed that younger men's semen had special properties that arrested the aging process and reyouthed the aging skin and the entire aged body. The study also found that absent husbands, drunkenness, women empowerment/ change of lifestyle, women/male youth vulnerability including the internet and social media created a perfect socioeconomic environment in which large age-gap taboo relationships emerged and flourished.
\end{abstract}

Key words: society, age-gap, heterosexual, romance,

\section{INTRODUCTION}

ociety prescribes what is socially acceptable and what is $\checkmark$ tagged taboo. Romantic large age-gap heterosexual relationships involving older men and younger women are looked at without peeled eyes. But a romantic relationship involving an older woman with a younger man, effect head shaking and tongue wagging among members of any society. The occurrence is looked at with unfavourable scrutiny because the 'large age difference between the woman and the man is seen as a mother/son relationship'(Proulx et al., 2006: 44). In such a social entanglement, an older woman is judged harshly by society (Lehmiller \& Agnew, 2011). She is boxed into a stereotypical label of being a 'sugar mummy', a 'cougar,' because according to society she is a seductress conwoman who uses her body, wealth, power, flattery and subtlety to drive out a younger man out of his moral defense into an intimate relationship with her.

Mature woman-younger man or granny- younger man romantic relationships are regarded as taboo because they violate society's mores. Society only award ample privileges to men to invite into romance their age-mates or to go in reverse and pick on young women who could be a decade or more years younger. These intimate relationships are sanctioned by society. They represent an unchallenged model of conducting intimate relationships. Everyone sticks to this social prescription and research finds that 'men tend to be more satisfied with younger wives and less satisfied with older wives,' (Lee \& McKinnish, 2017:3). Therefore, when an older heterosexual man tangles up with a younger woman in a romantic relationship the social waters of agitation, scrutiny and censure remain calm because society nods to this arrangement. Scholars affirm that the global familiar occurrence is for older men pairing with younger women (Ni Bhrolchain, 2006). It is a pattern observed across cultures (Nascimento, 2019). Large age-gap romance has been defined by social scientists as partner difference in years beyond 10years (Lehmiller \& Agnew, 2011). While older men continue to bask in the deployed societal favour as being the 'special ones', the 'chosen few' to wonder length and breadth in matters of partner choice for romance and do to as one pleases, women's corner of choices too is getting wider creating romantic dynamism. Proulx, Caron and Logue (2006) observe that as women become more socially and economically independent they become less likely to conform to traditional patterns characterized by older male/younger female arrangement (Proulx et al., 2006: 45). They exercise their earned liberty and freedom to choose who they should 
love and share intimacy with. Obviously, younger men's stamina and erectile capacities facilitate older women's efforts to challenge cultural expectations (Alarie 2019: 10) of adhering to older man yardstick. In search of freedom and adventure, they rebel against the established traditional standard of older male relationships. No wonder behind the social scenes, is a seething social pot filled with older women and younger men playing the chew-and-spit-out of long-held norms. They navigate their way out of social boundaries and twine in a romantic relationship.

In Zambia, older woman- younger man romantic relationships are socially abhorred because every older woman is perceived as a mother and every younger man a son but studies show that 'women tend to be more satisfied with younger husbands and less satisfied with older husbands', (Lee \& McKinnish, 2017:3). In September, 2020, as I scrambled for a seat in a small bus pirating between town and residential areas, within Chipata- Zambia, I looked around and saw animated faces of passengers. There were about 25 passengers nearly of equal gender. The atmosphere sounded lively. Passengers seemed to be locked in what appeared to be an interesting social discussion.

As I followed the discussion silently, the female passenger sitting to my immediate right turned to me and asked whether I had fully understood the subject under discussion to which I replied that I did not. She narrated that from different locations in the densely populated residential areas of Chipata- Zambia; two older women were caught romancing with younger men. Their husbands caught them and divorced them. I was stunned when passengers explained that age-gap relationships involving adult females and younger men bumped up everywhere, and that they had now become a common social problem across residential compounds in both low as well as high density areas.

In their stunning lively conversation, each passenger submitted a critical incident of a romantic taboo relationship of the past or the current from their area. From then on, I was motivated to conduct a study on this social phenomenon. The objective of this study was to find out whether large age-gap romantic relationships existed and if they did, under what socio-economic climate did they burst out and thrive.

\section{MATERIALS AND METHODS}

This was a unique study dealing with sensitive social taboos. Extreme care was taken to potential respondents. Assurance was made from the inception that it was not an investigative journalistic process meant to uncover social issues for publicity but rather it was a study aimed at learning from participants. When the purpose of the study was carefully explained, participants voluntarily accepted to participate. Being a new explorative study, the approach was qualitative. The study was conducted between October to December, 2020. For data collection, the study used the single-interviewper-participant design. Creswell (1998) suggested the range of 20-30 respondents to be sufficient for an interview-study. This study used 30 participants to achieve 30 individual interviews. All the targeted 30 participants agreed to participate in the study. To ensure study credibility and dependability, participants were sourced from both urban and rural areas. They included males and females of varying age ranges between 18 to 50years.

For further participant triangulation, respondents were drawn from various occupational stations namely garden boys, hairdressers, bicycle rider- transporters, civil servants, business people, and church leaders. It was intriguing to learn that the first few potential participants accosted for participation referred the researchers to other participants in a snowball arrangement because they felt that these had additional information either because they were witnesses or because they had heard from reliable sources. Participation was voluntary. Participants were given a comprehensive explanation on the purpose of the study, consent, and audio recording.

Anonymity and confidentiality were assured as participants' names were not recorded neither were participants allowed to introduce themselves using their names. Interviews were conducted with an atmosphere of informality so that participants could feel free to share their perspectives. Each interview lasted 60minutes. Refreshments were provided at the end of the interview for hydration only.

\section{RESULTS}

Question: What do you understand about age-gap romantic relationships involving older women with younger men?

This question was meant to gain a better understanding into what society meant about large age-gap romantic heterosexual relationships involving adult females and younger men. Themes that emerged from participants' responses have been categorized into definition of large age gap romantic relationship, prevalence of these relationships, and mode of existence. Respondents defined a large age-gap relationship involving an adult woman and a younger man as a romantic relationship in which an older female engaged in romance with a male of 5 or more years junior to her.

Respondents explained that it was normal for an older man to marry a younger woman because men 'never wear out sexually' said $95 \%$ of the respondents. For a woman, it was reported that the home stretch requirement was for her to get married to a man older than her even by 10 years or more. Respondents emphasized that for a woman to climb down the social ladder and hook up with a boy in a romantic relationship was maloza- a gross violation of social norms- a taboo. One rural male respondent said: Munalume anga kwatile mwanakazi mutontho wazaka zake zocepelera pa 5 years olo 10years nthawi ziyake kupitilila apo koma ngati mwanakazi wafuniwa na mwanalume mutontho wazaka zocepelera pa 5years olo kupitila apo aah ninshi ziliyenkhala bwino. Ayo ndiye maloza. Uyo ndiye umfwiti, a man is free to marry a woman younger than him by 5 years or 10 years 
even more but when a woman engages in a romantic relationship with a younger man who is 5 or 10 years or more then aah! that is gross violation of social norms. That's a taboo. That's witchcraft! (Male respondent).

A male church leader also sung along similar tunes; Tukamba kuti maloza ngati mwanalume mutontho alimucibwenzi na muzimai, we call it taboo when a younger man is in a romantic relationship with an older woman (Male respondent). An older female respondent from the rural area was very direct in her response, Kubvulila kamwamuna kang'ono kamene iwe mkazi usiyana nako zaka 5 olo kupitilila apo ni camanyazi kwa iwe mkazi. Si cabwino, to undress for a younger man who is 5 or more years junior is shameful for an older woman. It's no pleasant (Female respondent)

\section{Prevalence of age-gap romantic relationships}

When participants were asked whether large age-gap romantic relationships involving adult females and younger men existed, respondents used the following key words: common, widespread, rampant, universal, all over and everywhere to describe prevalence of such relationships. Respondents admitted that large age-gap romantic relationships involving older women and younger men have existed in both rural as well as in urban areas at negligible levels but social and economic changes has spiked their existence to unproportional levels in modern times. A female respondent described her version: Vibwenzi vaso venzeko nakudala koma mwapang'ono maningi cabe but manje vili paliponse mu komboni na muma yadi monse vilimo, such relationships existed in the past at negligible levels but now they are everywhere in both slams and low density areas (Female urban respondent).

A male respondent from an urban area said: Iyo nkhani ya ba zimai akulu kuyenda na anyamata icitika ndiponso yayenda pa cisawawa, the issue of mature females engaged in romantic relationships with younger men exists and its now rampant (Male urban respondent).

Another female respondent explained the following; Kudala nkhani ya so siyenze mveka koma manje izi zaso zajailika, in the past such things were rare but nowadays they have become common (Female respondent).

One respondent from the village countered that this kind of romantic relationship was rare in the village because older women were surrounded by kinfolks who monitored their social activities. Any social deviation from the old order invoked censure and in extreme cases disownment of the offender. The respondent also reported that villagers were more protective of family names from social dents because they wobbled and permanently stained family names for generations. In urban areas on the other hand, as opinionated by the same respondent, women were so remote from the kinfolks' social influence and power to right them up morally in case they strayed. Urban women therefore, used the characteristic of anonymity to engage in socially outlawed acts. Typical of rural mode of expression, the respondent analogically equated a rural mature woman to a fenced cow while an urban woman to a liberated individual who could make her own decisions and do anything to please herself.

Kumunzi vaso vucitika koma pang'ono kwenikweni cifukwa azimai onkhala olondowe namankhoswe ngati ng'ombe ili mukhola. Mzimai akasokoneza kucita bvameneibvo nishi omukalipila nthawiziyake kumudula mubanja. Kumunzi banthu ofuna lini kuifya zina la banja tu. Lomba mutauni mzimai onkhala omasuka kucita bvawaganiza kabili oziba kuti ba banja anga muongole akataika kuliye, such relationships are rare in the village because women are under the surveillance of their kinsmen like a chained cow. Any deviation invites censure and sometimes disownment because people in the village are so much into protecting family names unlike women in towns who do whatever they wish because they know that there is no family member who can censure them, (Male rural respondent).

Other rural participants gave a different version of the story. They explained that though mature woman-younger man romantic relationships did happen in the village, their scale was not alarming but high enough for social concern.

Siningakambe kuti nkhani iyo kuliye kumaminzi. Izi zucitika palilomba teti. Ziliko koma osati cisawawa monga mumatauni. Koma nase tayamba kuda nkhawa nda zateti zapaka, I cannot say these things don't happen. They happen in the village, though their scale is not so alarming like in urban areas but high enough for social concern (Female respondent, rural area).

\section{Evolving Trends}

Both rural and urban dwellers explained that the large age-gap relationships were unheard of in the 1970 s to 1980 s, became rare in the 1990s, occasional between 2000 and 2010 and common after 2010. The explanation given was that many females have become more independent economically. They had acquired tertiary education, were working or were involved in a viable business and had property. One old man from the rural area observed: when a woman becomes more equal to a man because she is educated or has property then she can make culturally weird decisions about her social life (Male respondent, rural). Another female recalled; such things were unheard of in the 1970s to 1980s, a bit in the 1990s then numbers began to rise slowly after 2000 to 2010 and it is now an outbreak after 2010 (Female urban respondent)

\section{Mode of existence}

Respondents reported that except for a few cases where family members had sanctioned such relationships into marriage, nearly all large age-gap relationships involving older women and younger men were conducted in secrecy. Respondents observed that younger men addressed their large age-gap female partners to their friends as 'auntie', 'mummy,' while older women partner addressed them as 'kitten,' 'sonny,' 
'Personal Assistant', 'Yard boy', 'Pet', and 'Slick' to disguise existence of a romantic relationship. Respondents added that rarely was the couple seen together in public. Rich older women wore large opaque glasses and remained in tinted vehicles while their younger partners dropped off in town or at college or university.

Respondents further explained that even if the couple held their romantic relationship tight to themselves it was still common for people to learn about it through either the younger man confiding in someone or the older lady sharing her sexual experiences with her younger partner to her fellow women. Sometimes people themselves made a huge discovery on their own by spotting the couple in awkward places and at odd times. Alternatively, it was also not uncommon for one of them to betray their relationship verbally to address the other by an affectionate name 'honey,' 'darling' or 'chocolate' in the presence of the third party or through stray romantic messages, nude photos or videos.

Respondents added that sometimes the relationship got exposed because the younger confided in someone or the older woman shared her pleasurable sexual encounters with her younger lover. In explaining about the confidential status of the romantic relationships between an older woman and a younger man one younger female respondent shared the following: They always keep it a secret because they know society does not allow. You will hear the younger man addressing the older woman as ba auntie, mummy or just ba madam, while the older woman will address her young dude, sonny, nephew, little friend or my pet (Female respondent).

One urban gentle man narrated how such relationships get exposed. These relationships are always kept a secret but sometimes the younger man would want to confide in someone they trust or the older woman fails to resist the temptation to share with her fellow women about her memorable sexual encounters with her younger male partner then comes the explosion of publicity, (Male respondent).

Question: What socio-economic factors catalyze the bursting out and thriving of large age-gap romantic relationships between older women and younger men?

This question was meant to explore factors that triggered the formation and thriving of large age-gap older woman romantic relationships. Responses from the respondents were segmented into the following themes: Traditional beliefs and practices, women empowerment/ lifestyle change, women/ male youth vulnerability, absent husbands and work demands.

\section{Traditional beliefs and practices}

The dimension of traditional beliefs and practices was inserted by rural respondents. Rural respondents narrated that in the village, there was an established belief that when an older woman had sex with a younger man the benefits to the older woman were enormous. She benefitted by taking into her own body youthful 'blood'. When an older woman sleeps with a younger man the older woman takes in his youthful blood (semen) (Female respondent).

Respondents used 'blood' for semen. Sometimes they used mphamvu (strength) for semen. The younger man's mphamvu (strength)(semen) is what older women covet because it smoothens a woman's skin (Female respondent). Respondents added that it was believed that 'blood' (semen) from a younger man had special revitalizing properties of re-youthing an aging woman. In brief terms, what respondents meant were that romance between an older female and a younger man meant an older woman drinking from the coveted fountain of youthfulness. It meant reversing the aging process. It meant arresting wrinkling. It meant giving life to aged cracking and dying skin.It meant improving the skin tone equal to the skin of a youth. Fired with the belief of revitalization, older women in villages surrendered their romantic dreams to younger men in the hope of recapturing their fading youthfulness. Other rural respondents explained that some older women in rural areas engaged in romantic relationships with male youths because of the existing traditional practice of consuming sexboosting herbs. They reported that sex-boosting herbs commonly called Mwanya

Alumbwana literally translated as 'Careful Young men'.

The Mwanya Alumbwana herb was prepared either as powder or decoction. The older woman consumed it in powdery form or added to porridge before consumption. Charged and ready for sex, the older woman through her actions, enticed a younger man for a romantic pleasurable experience. One respondents from the rural are reported that other older women carefully planned the sexual encounter with a male youth. Pretending she had piece work for him, she invited the targeted younger man to her garden.

Unsuspecting, the innocent younger man set off to work. But at the appointed time, she invited him to come over and assess her makeshift bathing shelter. As the younger went about making his assessment in the inner room she enticingly threw in a romantic story to lull the younger man's moral defences and before the younger man could recover she shed her clothes and exposed her nakedness and invited him for romance.

Kumunzi, azimai osebenzeshya mwanya, mwanya alumbwana. Akasebezesha mwanya, oziba kuti m'nyamata ndiye angakwanilishe $\mathrm{ku}$ ba fikishapo. In the village, older women use mwanya alumbwana (be careful young men). When they use it they entice a young man to satisfy their sexual cravings (Female respondent). Another female from the rural area added, other older women carefully plan and weave their web about the innocent younger man, trapped him and enjoyed him, (Female respondent).

\section{Women empowerment/lifestyle change}

Respondents from the urban area explained that due to women empowerment through education and property ownership, women had become more equal to men in both decision and 
choice making. This arrangement exhaled social changes with whom women conducted romantic relationships. Being in possession of property, money and power, came women's ability to make choices about who they would date and have sex with- either an older man or a younger man. Respondents reported these adult females were either single, married, divorced or widowed and were not willing to engage in a serious relationship leading to marriage. They were content to settle comfortably in a relationship that satisfied their sexual cravings. Women are now educated, they own property and have money. They live independently and so are able to make decisions and choices whether to hook up with a male youth or an older man (Female respondent). One younger male respondent narrated his experience in the following terms: $I$ had a female land lord who one day told me to be free with her and ask her anything I wanted and that she would give it to me freely. I was single she was widowed. She had courage to tell me that because she had property (Male respondent).

Other respondents explained that women empowerment had also brought a change in lifestyle in which older females frequented nightclubs and bars to drink and dance with lads whom they enjoy romance. When you go to nightclubs and bars, you will find a lot of older women who have stable-high paying jobs. Women who drive giant vehicles.

These elderly females drink alcohol and dance with boys. In their drunken state, they pick boys and engage in romantic activities with them and so that's how a relationship begins (Male respondent). Respondents reported that younger men were especially preferred in romantic relationships because they were energetic and lasted longer in bed thereby satisfying the older partner. Older women loved younger dudes because these prioritized satisfying their older women partners' sexual demands which was not the case with selfish weak older men who lasted seconds and were only interested in satisfying their own sexual desires. In the community older women say young dudes are energetic, can go on longer and usually prefer to satisfy a woman's sexual needs which is not the case with selfish older men. Older men are said to weaker in bed, last the shortest and are more interested in fulfilling their own desires (Female respondent).

\section{Absent/workaholic husband}

Respondents explained that older women with absent husbands because they were so attached to the computer leaving little or no time for their wives, created a perfect social environment where a large age-gap relationship between their wives and younger men emerged. Respondents reported that despite the property owned, money accumulated absence of romance made the wife to live a lonely social life without companionship and unfulfilled sexual demands. The situation was true for husbands were absent from home frequently for longer periods. Not wanting to engage in a romantic relationship which could easily raise neighbours' eye brows, the queen turned to a youth whom neighbours have always seen around such as the youthful garden boy, the relative to the husband. She groomed the boy slowly until the romantic relationship reached maturity. Men who are ever busy with the computer or busy drinking usually get disappointed because the queen gets hooked up in a romantic relationship with a garden boy (Male respondent). The other female respondent added: the lonely wife is acts very cleverly to groom the younger man (Female respondent).

\section{Vulnerability}

With regard to vulnerability, both rural and urban respondents explained that some older women who lacked food, clothes and other basic essentials sometimes preyed on younger men with a shop/makeshift shop, garden or baked scones for sale. They enticed younger men to begin a romantic relationship in exchange for soap, cooking oil, food, vegetables, charcoal etc. One younger male narrated his experience as follows: A tall light-skinned older woman would come to my garden to buy vegetables. One day she asked me if I was married. She told me that she was single and that I was free to go to her home and spend a night with her. I knew that what the older woman wanted was free vegetables in exchange for sex (Male respondent). Rural respondents added that it was common among younger men who operated hammer mills, shops, had viable gardens to be enticed into romantic relationships for free milling, free lotion, free vegetables etc.

Urban respondents reported that in urban areas, younger men were as vulnerable as some women in rural areas. These younger men lacked food, a safe home, money to pay for school/tuition fees. Well to do older women sometimes met these vulnerable youths on the street, in offices, in schools, colleges, universities, at church even in the nightclubs. They took these vulnerable male youths in their homes and assisted them with accommodation, food including their education. But the equation that began with care soon eventuated into full blown romantic relationships. The equation that begins with care for the vulnerable male youth soon graduates to an advanced romantic relationship with a female adult. Sometimes it begins with a younger man being in an environment where he is vulnerable. The older woman feels pity, offers to help, changes his life socially and economically then demands sexual favours in return (Female respondent).

\section{The internet and social media}

Respondents reported that the internet and social media has sparked dynamism across the landscape of romance. The respondents added that the internet and social media interface lonely adult females scarred with dark clouds of loneliness, rejection and disappointment but ready to see and feel the light of being accepted and valued by even younger men. These solitary souls in need of social bonding were ready to sacrifice soul, body and spirit to find somebody who would tell them they are worth and loved. Younger men taking it as a social gaming project have managed to win older women's affection. 
Internet and social media have to some extent bridged the traditional gap between older females and younger men to share the same online space, grow fond of each other and begin a romantic relationship. This is how a lot of younger men have found themselves marrying older women of other races or flirt with mature females within the country (Female respondent).

\section{Respondents' prediction for future generations}

Both rural and urban respondents' prediction was that the Zambian society was yet to put up with more of large age-gap romantic heterosexual relationships as more and more women standout economically, socially and politically. Respondents reported that men were generally not optimistic to marry wellto-do women for fear that their masculinity would be challenged.

\section{DISCUSSION}

Large age-gap romantic relationships between older females and younger men are hotly contested in society. This is because people marry partners where the 'man in the relationship is slightly older than his partner,' (Proulx et al., 2006: 44). This study set out to explore existence of large agegap female partner and younger male romantic relationship and to find out possible socioeconomic factors that fuel emergence of such relationships in Chipata- Zambia. The study found that society still labels older woman-younger man intimate relationships taboo and the older woman involved stigmatized heavily and called derogatory names such as 'sugar mummy' or 'big mama.' Proulx et al., (2006) in Vera, Berardo (1985) found that society looked down upon womanolder relationships because of incest taboo (Proulx et al., 2006:44).

In this study a large age-gap heterosexual relationship involving an adult female and a young man was defined as one with a partner age difference of 5years or more. The finding of this study goes out of the standard definition of partner difference in years beyond 10years (Lehmiller \& Agnew, 2011). This study identified several factors that fuel formation of older woman romantic relationships with younger men. These factors include traditional beliefs and practices, women empowerment/change of lifestyle, women/ younger men vulnerability and the internet and social media. About Traditional beliefs and practices, Maluleke (2012), wrote, 'traditional cultural practices reflect the values and beliefs held by members of a community for periods often spanning generations (Maluleke 2012:2) and these cultural practices centre around the sexuality of women and girls.

Scholars have written extensively about women empowerment and how this has changed their choices for sexual mates between older men and younger men. This study found that educated women, and women who owned property and money were more likely to defy cultural expectations of an older man relationship. These women were at liberty to choose younger men as intimate partners. Findings of this study support Proulx et al., (2006)'s findings that education appeared to play an important role in determining the likelihood that a woman will participate in an older womanyounger man romantic relationship (Proulx et al., 2006:45). This study also found that some vulnerable older women lacking basic necessities such as food, clothing and descent shelter sometimes enticed younger males for sexual encounters in exchange for food and material goods and services. These findings support the study findings by the United Nations High Commission for Refugees (2010) titled Driven by Desperation Transactional Sex as a Survival Strategy in Port-au-Prince IDP Camps older women due to extreme vulnerability, engaged in transactional sex with younger male perpetrators for food and other basic necessities (UNHCR, 2010).

This study also found that younger men spurred enthusiasm from older females because the younger males were branded young lions full of energy to last longer and keep their older romantic female partners sexually satisfied for longer periods. Some older women therefore by-passed older men and leagued with younger males in a romantic relationship. These findings support the findings by Alarie (2019). Alarie'(2019)'s study titled Sleeping With Younger Men: Women's Hypogamous Intimate Relationships demonstrated that older women preferred younger men for intimancy because 'younger men had abilities to have multiple erections which meant that their older women partners' sexual pleasure was prolonged' (Alarie, 2019: 7).

One participant in Alarie (2019)'s interview study with a report of involvement in romantic activities with younger men 10 to 20 years junior, reported that 'because of younger men's energy reserve he will be able to pleasure you longer to keep you in a state of bliss longer, so it has a big impact' (Older Female participant). This study found that some romantic older woman-younger male relationships emerged from the internet and social media. As younger men surfed dating sites online, they accidentally hit older women's profiles. Instead of ignoring, they expressed interest to date older women. Eager for a fresh start, older woman easily hooked up with male youths on the premise that they were agile in bed, lasted longer and addressed their older partners' sexual cravings before they themselves could reach orgasm. Arie's (2019) study found similar results as quoted by one older female participant who expressed shock when younger men in their early twenties invited her for a date, 'I say to them, listen, I am not forty-two, I am forty-eight,- as a way of discouraging them but they say, 'even better,' (Older Female participant). In the same study, Alarie (2019 found that older females loved younger men because they put in more effort during sexual encounters and that they satisfied a woman's sexual needs first before theirs (Alarie 2019:4).

\section{CONCLUSION}

Older woman -younger man romantic relationship is despised by society because it violates society's mores. However, as 
more women break the poverty/ patriarchal barrier and become independent, social changes are brought to the fore in which established social norms are challenged and the old order standards placed by society turned upside-down. In recent times, urban areas and to a lesser extent rural areas, older women are bending low and hooking up in romantic relationships with younger men double their ages sometimes even more. It is certainly clear that the trend will never be reversed.

\section{RECOMMENDATION}

The study recommends sensitization campaigns to naive youth in schools and colleges to be on the lookout against older women preying on younger men taking advantage their vulnerability, innovativeness and hard work. Older woman romantic relationship is never built on genuine love but rather on transactional processes which quickly wind up immediately the other feel that have achieved what they wanted.

Table1.Demographic characteristics of participants

\begin{tabular}{|c|c|c|c|c|}
\hline Variables & \multicolumn{2}{|c|}{ Urban Respondents } & \multicolumn{2}{|c|}{ Rural Respondents } \\
\hline \multirow{2}{*}{ Gender } & Male & Female & Male & Female \\
\hline & $7(23.3 \%)$ & $8(26.6 \%)$ & $7(23.3 \%)$ & $8(26.6 \%)$ \\
\hline \multirow{4}{*}{$\begin{array}{l}\text { Age( in } \\
\text { Years) }\end{array}$} & $18-25$ & $3(10 \%)$ & $18-25$ & $3(10 \%)$ \\
\hline & $26-33$ & $5(16.6 \%)$ & $26-33$ & $5(16.6 \%)$ \\
\hline & $34-41$ & $3(10 \%)$ & $34-41$ & $3(10 \%)$ \\
\hline & $42-50$ & $4(13.3 \%)$ & $42-50$ & $4(13.3 \%)$ \\
\hline \multirow{4}{*}{$\begin{array}{l}\text { Marital } \\
\text { status }\end{array}$} & Single & 5 & Single & 4 \\
\hline & Married & 10 & Married & 10 \\
\hline & Divorced & 0 & Divorced & 0 \\
\hline & Widowed & 0 & Widowed & 1 \\
\hline \multirow{6}{*}{$\begin{array}{l}\text { Education } \\
\text { levels }\end{array}$} & \multicolumn{2}{|c|}{$\begin{array}{l}\text { Senior secondary not } \\
\text { completed } 0\end{array}$} & \multicolumn{2}{|c|}{$\begin{array}{l}\text { Senior secondary not } \\
\text { completed } 10(33.3 \%)\end{array}$} \\
\hline & \multicolumn{2}{|c|}{$\begin{array}{c}\text { Senior secondary } \\
\text { completed } 8(26.6 \%)\end{array}$} & \multicolumn{2}{|c|}{$\begin{array}{c}\text { Senior secondary } \\
\text { completed } 5(16.6 \%)\end{array}$} \\
\hline & \multicolumn{2}{|c|}{$\begin{array}{c}\text { College not yet completed } \\
0\end{array}$} & \multicolumn{2}{|c|}{$\begin{array}{c}\text { College not yet completed } \\
0\end{array}$} \\
\hline & \multicolumn{2}{|c|}{$\begin{array}{c}\text { College completed } \\
23.3 \%)\end{array}$} & \multicolumn{2}{|c|}{ College completed $\quad 0$} \\
\hline & \multicolumn{2}{|c|}{$\begin{array}{c}\text { University not Completed } \\
0 \\
\end{array}$} & \multicolumn{2}{|c|}{$\begin{array}{c}\text { University not Completed } \\
0\end{array}$} \\
\hline & \multicolumn{2}{|c|}{ University Completed 0} & \multicolumn{2}{|c|}{ University Completed 0} \\
\hline \multirow[t]{3}{*}{ Occupation } & $\begin{array}{c}\text { Civil } \\
\text { Servant }\end{array}$ & $3(10 \%)$ & $\begin{array}{c}\text { Civil } \\
\text { Servant }\end{array}$ & 0 \\
\hline & $\begin{array}{l}\text { Church } \\
\text { leader }\end{array}$ & $2(6.6 \%)$ & $\begin{array}{l}\text { Church } \\
\text { leader }\end{array}$ & $2(6.6 \%)$ \\
\hline & Garden boy & $2(6.6 \%)$ & Farmer & $7(23.3 \%)$ \\
\hline
\end{tabular}

\begin{tabular}{|l|c|c|c|c|}
\hline & $\begin{array}{c}\text { Business } \\
\text { man/woman }\end{array}$ & $3(10 \%)$ & $\begin{array}{c}\text { Business } \\
\text { man/woman }\end{array}$ & $1(3.3 \%)$ \\
\hline & $\begin{array}{c}\text { Bicycle } \\
\text { rider } \\
\text { transporter }\end{array}$ & $5(16.6 \%)$ & $\begin{array}{c}\text { Bicycle } \\
\text { rider } \\
\text { transporter }\end{array}$ & $5(16.6 \%)$ \\
\hline
\end{tabular}

\section{AUTHORS' CONTRIBUTIONS}

JT was responsible for the study conception and design, data collection, and analysis. PM edited the manuscript.

\section{ACKNOWLEDGEMENTS}

The authors are grateful to all the participants who participated in the study and all the significant gatekeepers who gave permission to ensure the study was conducted.

\section{REFERENCES}

[1] Creswell, J.W.(1998). Qualitative inquiry and research design: Choosing among five traditions. Thousand Oaks, CA:Sage Publications

[2] Lee, Wang-Sheng, McKinnish, T. (2017). The Marital Satisfaction of Different -Aged couples, Discussion Paper Series IZA DP No. 10863

[3] Lehmiller, J., Agnew, C.(2011). 'May- December Paradoxes: An Exploration of Age-Gap Relationships in Western Society'. Department of Psychological Sciences Faculty Publications. Paper 27. https://docs.lib.purdue.edu/psych pubs/27

[4] Milaine, A. (2019). Sleeping with Younger Men: Women's accounts of Sexual Interplay in Age- Hypogamous intimate Relationships. The Journal of Sex Research, Doi: 10.1080/00224499.2019.1574704

[5] Maluleke, M.J.(2012). Culture, Tradition, Custom, Law and Gender Equality. PER/PELJ(2012)(15)1

[6] Nascimento, B.S. (2019). Age Differences in Marriage Partners. In: Shackelford T., Weekes-Shackelford V. (eds). Encyclopaedia of Evolutionary Psychological Science. Springer, Cham https://doi: org/10.1007/978-3319-16999-6_233-1

[7] Ni Bhrolchain, M.(2006). In Lehmiller, J., Agnew, C.(2011). 'May- December Paradoxes: An Exploration of Age-Gap Relationships in Western Society'. Department of Psychological Sciences Faculty Publications. Paper 27. https://docs.lib.purdue.edu/psych pubs/27

[8] Proulx, N., Caron, S.L., Logue, M.E. (2006). 'Older Women/Younger Men'. Journal of Couple \& Relationship Therapy, $\quad 5:$ 4, 43-64 DOI: 10.1300/J398V05N04_03HTTP://DX.DOI.org/10.1300/J398v05n 04 03

[9] United Nations High Commission for Refugees (2011). Driven by Desperation. Transactional Sex as a Strategy for Survival in Portau-Prince IDP Camps

[10] Vera, H., Berardo, D.H., F.M.(1985). In Proulx, N., Caron, S.L., Logue, M.E. (2006). 'Older Women/Younger Men'. Journal of Couple \& Relationship Therapy, 5: 4, 43-64 DOI: 10.1300/J398V05N04_03HTTP://DX.DOI.org/10.1300/J398v05n 04_03 